\title{
HUBUNGAN POLA PEMBERIAN MAKANAN PENDAMPING ASI DENGAN BERAT BADAN BAYI USIA 6-12 BULAN DI KELURAHAN WONOREJO KABUPATEN KARANGANYAR
}

\section{Correlation Between Breastfeeding Complementary Feeding Patterns And Infant Body Weight 6-12 Months}

\author{
Hardiningsih $^{1)}$, Sri Anggarini P(2), Fresthy Astrika Yunita ${ }^{3)}$, Agus Eka Nurma Yuneta ${ }^{4)}$, M. \\ Nur Dewi Kartikasari ${ }^{5)}$, Ropitasari ${ }^{6}$ \\ ${ }^{*}$ Prodi D III Kebidanan, FK, Universitas Sebelas Maret, Jl. Ir. Sutami 36A, Kentingan Surakarta 57126 \\ telp. (0271) 662622
}

E-mail : mrshardiningsih@gmail.com

\begin{abstract}
ABSTRAK
Latar Belakang: Pola pemberian makanan sangat mempengaruhi pertumbuhan berat badan bayi. ASI saja tidak bisa memenuhi semua kebutuhan energi dan zat gizinya, karena pemenuhan gizi bayi dari ASI hanya sebesar $65-80 \%$. Pola pemberian makanan pada bayi sangat berhubungan dengan berat badan bayi, karena pola tersebut memberikan gambaran frekuensi pemberian makan, jenis/ bentuk makanan maupun jumlah takaran yang diberikan. Tujuan penelitian ini yaitu enganalisis hubungan pola pemberian makanan pendamping ASI dengan berat badan bayi usia 6-12 bulan.

Metode penelitian: Desain penelitian adalah cross sectional. Penelitian dilakukan di posyandu kelurahan Wonorejo Kabupaten Karanganyar. Populasi yang digunakan dalam penelitian ini adalah ibu yang mempunyai bayi berusia 6-12 bulan di posyandu kelurahan Wonorejo. Teknik cluster random sampling. Alat ukur kuesioner, lembar wawancara, timbangan bayi dan KMS. Analisis data dengan uji statistik Chi Square.

Hasil penelitian: Mayoritas responden yang diteliti memberikan MP-ASI secara tepat, baik dalam hal bentuk MP-ASI (65\%), frekuensi pemberian (72.2\%), dan jumlah takaran (70\%). Pada variabel berat badan yaitu mayoritas berat badan bayi meningkat $(17.5 \%)$. Selanjutnya, terdapat hubungan bentuk MP-ASI terhadap berat badan $(\mathrm{OR}=18.75$; $\mathrm{p}=0.02)$; terdapat hubungan frekuensi pemberian MP-ASI terhadap berat badan $(\mathrm{OR}=$ $11.25 ; \mathrm{p}=0.04)$; serta terdapat hubungan jumlah takaran MP-ASI terhadap berat badan $(\mathrm{OR}=27 ; \mathrm{p}<0.001)$.

Kesimpulan: Pada penelitian ini, mayoritas responden yang diteliti telah memberikan MPASI sesuai pola yang dianjurkan. Pada variabel berat badan yaitu mayoritas berat badan bayi meningkat. Selanjutnya, terdapat hubungan bentuk, frekuensi, serta jumlah takaran MP-ASI terhadap berat badan.
\end{abstract}

Kata Kunci: Pola pemberian makan, MP-ASI, Berat badan bayi 


\begin{abstract}
Background: The pattern of feeding is really influence to the growth of the baby's weight. Breast milk itself cannot cover all the energy and nutrient needs, because the fulfillment of infant nutrition from breast milk is only $65-80 \%$.. The pattern of feeding the baby is closely related to the baby's weight, because the pattern provides a description frequency of feeding, the type of food and the amount of the dose given. The aim of this reaearch is to analyze the correlation between breastfeeding complementary feeding patterns and infant body weight 6-12 months.
\end{abstract}

Methods: The research design is a cross sectional. The study was conducted at the Posyandu in Wonorejo, Karanganyar Regency. The population used in this research is mothers who have babies 6-12 months old in Wonorejo Posyandu. Cluster random sampling technique. Questionnaire measuring instruments, interview sheets, baby scales and KMS. Data analysis with Chi Square statistic test.

Results: The majority of respondents surveyed gave MP-ASI appropriately, both in terms of the type of MP-ASI (65\%), frequency of distribution (72.2\%), and total dose (70\%). In the variable body weight, the majority of the baby's body weight increased (17.5\%). Furthermore, there is a correlation between the type of MP-ASI and body weight $(O R=$ 18.75; $p=0.02)$; there is a correlation between the frequency of MP-ASI giving to body weight $(O R=11.25 ; p=0.04)$; and there is a correlation between the number of MP-ASI doses for body weight $(O R=27 ; p<0.001)$.

Conclusion: In this research, the majority of respondents have given MP-ASI according to the recommended pattern. In the weight variable, the majority of the baby's body weight increases. Furthermore, there is a correlation between the types, frequency and the amount of MP-ASI doses to the body weight.

Keywords: The pattern of feeding, MP-ASI, Infant body weight 


\begin{abstract}
PENDAHULUAN
Setahun pertama kehidupan bayi atau anak pada usia 0-12 bulan merupakan masa pertumbuhan pesat untuk fisiknya dan memasuki usia 6 bulan perlu mendapat makanan pendamping selain ASI untuk pertumbuhan fisik yang optimal $^{[11]}$. Pertumbuhan bayi dapat dipantau dengan melihat hasil penimbangan yang tercatat pada KMS (Kartu Menuju Sehat) ${ }^{[52]}$. Pertumbuhan dan perkembangan bayi tidak hanya bergantung pada proses kelahiran maupun perawatan tetapi juga dipengaruhi oleh pola pemberian makanan ${ }^{[22]}$. Memasuki 6 bulan keatas bayi mulai membutuhkan tambahan makanan pendamping selain ASI.
\end{abstract}

ASI saja tidak bisa memenuhi semua kebutuhan energi dan zat gizinya, karena pemenuhan gizi bayi dari ASI (Air Susu Ibu) hanya sebesar $65-80 \%$. Hal ini disebabkan oleh organ pencernaan bayi mulai berfungsi lebih baik, sehingga bayi sudah boleh diberikan MP-ASI atau makanan pendamping $\mathrm{ASI}^{[17]}$. Pola pemberian makanan pada bayi sangat berhubungan dengan berat badan bayi, karena pola tersebut memberikan gambaran frekuensi pemberian makan, jenis/ bentuk makanan maupun jumlah takaran yang diberikan ${ }^{[52]}$.

Berdasarkan hasil penelitian Dewi (2010) berjudul Hubungan Pola Pemberian Makanan Pendamping ASI (MP-ASI) dengan Status Gizi pada balita usia $6-12$ bulan di Desa Kaliori Kecamatan Kalibagor Kabupaten Banyumas menunjukan bahwa sebagian besar mempunyai pola pemberian MPASI cukup baik yaitu sebanyak 25 balita (51\%) dengan memiliki status gizi yang baik sebanyak 43 orang $(88 \%)^{[12]}$. Penelitian lain oleh Sakti (2013) berjudul Hubungan Pola Pemberian MP-ASI dengan Status Gizi Anak Usia 6-23 bulan di Wilayah Pesisir Kecamatan Tallo Kota Makassar Tahun 2013 menunjukan bahwa lebih banyak anak berstatus gizi buruk/kurang yang mendapatkan frekuensi pemberian MP-ASI kurang yaitu sebanyak 26 anak $(38,2 \%)$.

Secara nasional, prevalensi berat badan kurang mengalami peningkatan dari tahun 2007 sebanyak 18,7\%, tahun 2010 sebanyak 17,9 \% dan pada tahun 2013 sebanyak 19,6\% (Riskesdas, 2013). Berat badan yang kurang merupakan suatu indikator terjadinya gizi buruk. Gizi buruk terutama pertumbuhan yang terhambat merupakan sebuah masalah kesehatan yang utama di Indonesia ${ }^{[55]}$. Di provinsi Jawa Tengah kejadian gizi buruk pada tahun 2012 berjumlah $1.131 \quad(0,06 \%)$ (Dinkes Provinsi Jawa Tengah, 2012). Kejadian gizi buruk secara dini diidentifikasi melalui penimbangan berat badan bayi. Karanganyar merupakan salah satu kabupaten yang mempunyai jumlah penduduk sebanyak 861.845 jiwa yang terletak disebelah timur dari kota Surakarta. Peranan wanita atau ibu rumah tangga merupakan penentu dalam usaha perbaikan gizi keluarga. Tingkat pendidikan ibu yang baik akan memberikan pemahaman yang baik pula pada ibu untuk meningkatkan status gizi balita.

Kasus gizi pada balita di Kabupaten Karanganyar sendiri dari tahun ke tahun mengalami perubahan yang fluktuatif. Tahun 2013 persentase kejadian gizi kurang 2,69\%, dan gizi buruk 0,31\%. Kemudian di tahun 2014 persentase bayi dua tahun dengan berat badan dibawah garis merah sebesar $0,45 \%$ dan balita dengan berat badan dibawah garis merah sebesar $0,83 \%{ }^{[15]}$. Senada dengan data ini, Depertemen kesehatan kabupaten Karanganyar mengatakan Pada tahun 2014 di Kabupaten Karanganyar terdapat $6,8 \%$ balita kekurangan gizi.

\section{METODE}

Jenis penelitian merupakan penelitian analitik observasional. Desain penelitian yang digunakan adalah cross sectional untuk mengetahui hubungan pola pemberian makanan pendamping ASI dengan berat badan bayi usia 6-12 bulan. 
Variabel independen dan variabel dependen dalam penelitian ini diteliti hanya sekali secara bersamaan, dalam periode waktu tertentu.

Lokasi penelitian di Posyandu Kelurahan Wonorejo Kabupaten Karanganyar. Waktu penelitian dilakukan selama 5 (enam) bulan, yaitu pada bulan Februari hingga Juli 2019.

Populasi penelitian yaitu semua bayi di Posyandu Kelurahan Wonorejo Kabupaten Karanganyar serta ibu yang mempunyai bayi usia 6-12 bulan di Posyandu Kelurahan Wonorejo. Teknik sampel yang digunakan adalah cluster random sampling.

Alat ukur dalam penelitian ini yaitu kuesioner yang dilakukan secara langsung dan lembar panduan wawancara. Sedangkan untuk mengukur berat badan bayi dengan mengukur berat badan menggunakan dacin atau timbangan injak serta KMS (Kartu Menuju Sehat).

Analisis data dilakukan secara komputerisasi menggunakan program SPSS 20.0 dengan uji statistik ChiSquare.

\section{HASIL}

1. Hasil Analisis Univariat

Analisis variabel penelitian secara univariat menjelaskan tentang distribusi variabel penelitian yang meliputi variabel pola pemberian MPASI yaitu bentuk MP-ASI, frekuensi pemberian, dan jumlah takaran dengan berat badan bayi. Tabel hasil analisis univariat dijelaskan pada tabel 1 akan membahas mengenai jumlah (n) dan persentase (\%) pada setiap variabel.

Tabel 1. Tabel Univariat Variabel

\begin{tabular}{|c|c|c|c|c|}
\hline \multirow{2}{*}{ Variabel } & \multirow{2}{*}{$\mathbf{n}$} & \multirow{2}{*}{$\%$} & \multicolumn{2}{|c|}{ Total } \\
\hline & & & $\mathbf{n}$ & $\%$ \\
\hline \multicolumn{5}{|l|}{ Bentuk MP-ASI } \\
\hline Sesuai & 26 & 65 & \multirow{2}{*}{40} & \multirow{2}{*}{100} \\
\hline Tidak Sesuai & 14 & 35 & & \\
\hline \multicolumn{5}{|l|}{ Frekuensi Pemberian } \\
\hline Sesuai & 29 & 72.5 & \multirow{2}{*}{40} & \multirow{2}{*}{100} \\
\hline Tidak Sesuai & 11 & 27.5 & & \\
\hline \multicolumn{5}{|l|}{ Jumlah takaran } \\
\hline Sesuai & 28 & 70 & \multirow{2}{*}{40} & \multirow{2}{*}{100} \\
\hline Tidak Sesuai & 12 & 30 & & \\
\hline \multicolumn{5}{|l|}{ Berat badan } \\
\hline Kenaikan & 33 & 82.5 & \multirow{2}{*}{40} & \multirow{2}{*}{100} \\
\hline Tidak mengalami kenaikan & 7 & 17.5 & & \\
\hline
\end{tabular}

Tabel 1 menunjukkan bahwa mayoritas responden yang diteliti memberikan MP-ASI secara tepat baik dalam hal bentuk MP-ASI (65\%), frekuensi pemberian $(72.2 \%)$, dan jumlah takaran (70\%). Selanjutnya, pada variabel berat badan yaitu mayoritas berat badan bayi meningkat (17.5\%).

2. Hasil Analisis Bivariat Analisis variabel penelitian secara bivariat menggunakan uji chi-square untuk menjelaskan tentang hubungan variabel dependen dengan variabel independen, yaitu hubungan bentuk MP-ASI dengan berat badan, hubungan frekuensi pemberian dengan berat badan, dan hubungan jumlah takaran dengan berat badan. Tabel 2 membahas mengenai hubungan variabel pola pemberian MP-ASI dengan variabel berat badan. 
Tabel 2. Tabel Bivariat Pola MP ASI

\begin{tabular}{|c|c|c|c|c|c|c|}
\hline \multirow{2}{*}{ Variabel } & \multirow{2}{*}{$\mathbf{n}$} & \multirow{2}{*}{$\%$} & \multicolumn{2}{|c|}{ Total } & \multirow{2}{*}{ OR } & \multirow[b]{2}{*}{$\mathbf{p}$} \\
\hline & & & $\mathrm{n}$ & $\%$ & & \\
\hline \multicolumn{7}{|l|}{ Bentuk MP-ASI } \\
\hline Sesuai & 14 & 65 & \multirow{2}{*}{40} & \multirow{2}{*}{100} & 18.75 & \multirow[t]{2}{*}{0.02} \\
\hline Tidak Sesuai & 26 & 35 & & & & \\
\hline \multicolumn{7}{|l|}{$\begin{array}{l}\text { Frekuensi } \\
\text { Pemberian }\end{array}$} \\
\hline Sesuai & 29 & 72.5 & \multirow{2}{*}{40} & \multirow{2}{*}{100} & 11.25 & \multirow[t]{2}{*}{0.04} \\
\hline Tidak Sesuai & 11 & 27.5 & & & & \\
\hline \multicolumn{7}{|l|}{ Jumlah takaran } \\
\hline Sesuai & 28 & 70 & \multirow{2}{*}{40} & \multirow{2}{*}{100} & \multirow{2}{*}{27} & \multirow{2}{*}{$<0.001$} \\
\hline Tidak Sesuai & 12 & 30 & & & & \\
\hline
\end{tabular}

Analisis bivariat menjelaskan tentang hubungan satu variabel independen dengan variabel dependen. Pada penelitian ini, analisis bivariat yang digunakan adalah uji Chi-square. Hasil analisis menggunakan uji Chi-square pada Tabel 2 untuk menunjukkan bahwa :

a. Hubungan bentuk MP-ASI dengan berat badan : terdapat hubungan bentuk MP-ASI terhadap berat badan. Bayi yang mendapat bentuk MP_ASI sesuai umur memiliki kemungkinan 18.75 kali lebih besar mengalami kenaikan berat badan yang sesuai umur $(\mathrm{OR}=18.75 ; \mathrm{p}=0.02)$.

b. Hubungan frekuensi pemberian MPASI dengan berat badan : terdapat hubungan frekuensi pemberian MPASI terhadap berat badan. Bayi yang mendapat frekuensi pemberian MP_ASI tepat sesuai umur memiliki kemungkinan 11.25 kali lebih besar mengalami kenaikan berat badan yang sesuai umur $(\mathrm{OR}=11.25$; $\mathrm{p}=0.04$ ).

c. Hubungan jumlah takaran MP-ASI dengan berat badan : terdapat hubungan jumlah takaran MP-ASI terhadap berat badan. Bayi yang mendapat jumlah takaran MP_ASI tepat sesuai umur memiliki kemungkinan 27 kali lebih besar mengalami kenaikan berat badan yang sesuai umur $(\mathrm{OR}=11.25$; $\mathrm{p}<0.001)$.

\section{PEMBAHASAN \\ Pola Pemberian Makanan Pendamping ASI}

Rekomendasi dari WHO bayi harus diberi ASI eksklusif selama enam bulan pertama kehidupan untuk mencapai pertumbuhan, perkembangan, dan kesehatan yang optimal. Setelah itu, untuk memenuhi kebutuhan gizi, bayi harus menerima Makanan Pendamping ASI (MP-ASI) yang memadai dan aman, sambil terus menyusui hingga dua tahun atau lebih. Pemberian MP-ASI didefinisikan sebagai proses yang dimulai ketika ASI saja tidak lagi cukup untuk memenuhi kebutuhan gizi bayi, oleh karena itu makanan dan cairan lain diperlukan, bersama dengan pemberian $\mathrm{ASI}^{[58]}$. Pola pemberian makanan pada bayi harus disesuaikan dengan usianya, diberikan secara bertahap, baik bentuk, jenis makanan, frekuensi, ataupun jumlahnya ${ }^{[52]}$.

Menurut ahli nutrisi anak, kesiapan perkembangan dan kemampuan untuk bayi dalam mentolerir makanan yang dikonsumsi terjadi pada usia 6 bulan. Selama periode ini, saluran pencernaan akan memiliki sistem pertahanan yang baik sehingga dapat meminimalkan risiko reaksi alergi pada bayi. Selain itu, sistem neuromuskuler juga cukup matang, sehingga bayi telah memiliki kemampuan untuk mengenali makanan, mengunyah dan menelan makanan, serta membedakan 
keragaman dalam rasa dan warna makanan $^{[1]}$.

\section{Bentuk Makanan Pendamping ASI}

Hasil pada penelitian ini mengenai jenis/bahan MP ASI yang diberikan kepada bayinya diperoleh hasil dari 40 bayi terdapat 26 bayi (65\%) dengan pemberian bentuk MP ASI yang sesuai anjuran (sesuai tabel 4.1) sedangkan 14 bayi (35\%) dengan pemberian bahan/jenis MP ASI yang tidak sesuai. Hasil penelitian ini relevan dengan penelitian yang dilakukan oleh Olatona et al. (2017) mengenai pengetahuan tentang MP-ASI, praktik, dan keragaman pola makan di kalangan ibu dari anak balita di komunitas urban di Negara Bagian Lagos, Nigeria. Hasil penelitian tersebut menunjukkan bahwa mayoritas responden yaitu sebanyak $192(56,8 \%)$ telah memberikan bentuk MP-ASI yang tepat kepada anaknya $^{[44]}$.

Menurut Jafar (2012) makanan tambahan mulai diberikan ketika anak berusia 6 bulan. Usia 6-8 bulan berupa bubur kental/ makanan keluarga yang dilumatkan. Dari usia 9-11 bulan berupa makanan lunak yaitu makanan keluarga yang dicacah maupun makanan dengan potongan kecil yang dapat dipegang. Dari usia 12 bulan berupa makanan yang diirisiris maupun makanan keluarga ${ }^{[28]}$. Menurut Nasar (2014) tekstur dan konsistensi dimulai dengan tekstur yang lembut/ halus dan konsistensinya masih agak encer, secara bertahap tekstur dan konsitensinya ditingkatkan menjadi makin kental sampai padat dan kasar.

Bentuk MP-ASI yang paling tepat untuk makanan bayi bergantung pada usia dan perkembangan neuromuskuler bayi. Selain itu, pada saat bayi mulai mengonsumsi MP-ASI, bayi memerlukan waktu untuk membiasakan diri pada tekstur makanan baru tersebut ${ }^{[28][58]}$. Jenis makanan dibedakan berdasarkan bentuk makanan, yaitu makanan lumat, makanan lembek dan makanan orang dewasa/ makanan keluarga. Makanan lumat adalah makanan yang dimasak/ disajikan dalam bentuk halus (contohnya: bubur tepung, nasi atau pisang lumat, bubur beras encer). Makanan lembek adalah makanan yang dimasak/ disajikan dalam bentuk lunak (nasi tim, lauk-pauk dan sayur). Makanan orang dewasa/ makanan keluarga adalah makanan yang dimasak/ disajikan dalam bentuk biasa (nasi, lauk - pauk dan sayur $)^{[5]}$.

Bayi yang diberikan jenis/bentuk MP ASI yang tidak sesuai usia sebanyak 14 bayi (35\%). Pemberian MP-ASI harus memperhatikan Angka Kecukupan Gizi (AKG) yang dianjurkan berdasarkan kelompok umur dan bentuk makanan yang sesuai perkembangan usia bayi. Terkadang terdapat ibu yang telah memberikan MP-ASI pada usia dua atau tiga bulan, padahal di usia tersebut kemampuan pencernaan bayi belum siap menerima makanan tambahan. Akibatnya banyak bayi yang mengalami diare. Masalah gangguan pertumbuhan pada usia dini yang terjadi di Indonesia diduga kuat berhubungan dengan banyaknya bayi yang sudah diberi MP-ASI sejak usia satu bulan bahkan sebelumnya dengan bentuk yang tidak sesuai $^{[41]}$.

Selanjutnya, Narendra (2008) menyatakan bahwa terlalu lambat mulai memberikan MP ASI juga kurang baik, sebab dapat menyebabkan bayi kurang gizi dan dapat menghambat keterampilan makan bayi. Selain itu juga tidak sesuai dengan perkembangan kemampuan bayi dalam mengunyah sehingga perlu diberikan makanan yang lebih kasar. Hal ini didukung dengan hasil penelitian yang dilakukan oleh Romero-Velarde et al. (2016), bahwa pemberian MP-ASI yang terlalu lambat memiliki efek negatif pada tingkat pertumbuhan dan meningkatkan kemungkinan kejadian malnutrisi karena pemberian ASI eksklusif tidak memenuhi kebutuhan energi dan protein setelah usia enam bulan; kekurangan zat besi, seng, dan anemia karena terlambatnya pengenalan makanan seperti daging maupun makanan dengan kandungan sumber mineral; serta gangguan makan 
pada bayi, seperti penolakan makanan padat, muntah, maupun tersedak ${ }^{[48]}$.

\section{Frekuensi Pemberian Makanan Pendamping ASI}

Hasil penelitian yang telah dilakukan pada 40 ibu bayi usia 6 - 12 bulan didapatkan hasil pada tabel 4.1 menunjukan bahwa frekuensi pemberian MP ASI bayi usia 6 12 bulan di Kelurahan Wonorejo sebagian besar adalah sesuai dengan anjuran yaitu sebanyak 29 responden $(72.5 \%)$ dan yang tidak sesuai sebanyak 11 (27.5\%). Hasil ini hampir serupa dengan penelitian yang dilakukan oleh Aemro et al. (2013) mengenai keragaman makanan dan praktik frekuensi makanan pada bayi dan anak usia 6-23 bulan di Ethiopia. Penelitian tersebut menunjukkan bahwa lebih dari separuh responden yaitu 55.3\% telah memberikan MP-ASI dengan frekuensi yang sesuai.

Menurut Nasar (2014) mulai pemberian MP ASI pada saat yang tepat sangat bermanfaat bagi pemenuhan kebutuhan nutrisi. Frekuensi pemberian makanan selain ASI secara bertahap sampai seluruh kebutuhan anak terpenuhi. Studi terbaru yang dilakukan oleh (Owais et al., 2016) menunjukkan bahwa praktik pemberian MP-ASI dengan frekuensi yang sesuai memprediksi hasil pertumbuhan yang lebih baik pada anak Asia Selatan. Selanjutnya, dalam penelitian Crum et al. (2013) di pedesaan Bangladesh, anak yang diberi MP-ASI dengan frekuensi yang sesuai pada usia 9 bulan memiliki hasil tinggi badan yang lebih baik untuk usia serta lebih kecil kemungkinannya terhambat pada usia 24 bulan. Kemudian di Nepal, frekuensi pemberian MP-ASI dan keragaman diet minimum berhubungan positif dengan tinggi badan untuk anak usia 6-23 bulan. Kombinasi frekuensi yang sesuai dan keragaman diet minimum memiliki efek terbesar pada indikator pertumbuhan anak.

Cara pemberian MP-ASI diberikan sesuai dengan tanda lapar dan nafsu makan yang ditunjukan bayi serta frekuensi dan cara pemberiannya juga harus sesuai dengan usia bayi. Frekuensi pemberian MP-ASI yang diharapkan untuk menyediakan kebutuhan energi harian perlu memperhatikan kepadatan energi minimum yang disarankan $(0,8$ $\mathrm{kkal} / \mathrm{gr}$ ) beserta asumsi kapasitas lambung bayi yaitu $30 \mathrm{gr} / \mathrm{kg}$ berat badan. Di samping pemberian ASI, anjuran frekuensi makan pada usia 6 - 8 bulan yaitu diberikan 2 - 3 kali makan perhari. Untuk usia 9 - 11 bulan diberikan 3 - 4 kali sehari. Untuk usia $12-24$ bulan diberikan 3- 4 kali sehari ditambah 1 sampai 2 kali makanan selingan ${ }^{[1][58]}$.

Dalam penelitian ini, bayi dengan frekuensi pemberian makan yang tidak sesuai sebanyak 11 (27.5\%). Aguayo (2017) dalam penelitiannya mengungkapkan bahwa frekuensi pemberian MP-ASI yang tidak sesuai terkait dengan tingginya tingkat stunting anak di Asia Selatan. Hal ini didukung dengan hasil penelitian yang dilakukan oleh Udoh dan Amodu (2016) di Nigeria di mana anak-anak yang tidak menerima frekuensi MP-ASI yang sesuai lebih cenderung terhambat pertumbuhannya daripada yang menerima frekuensi MPASI yang sesuai (OR 1,57; 95\% CI 1,534,03). Frekuensi pemberian MP-ASI yang tidak sesuai dapat disebabkan oleh keterbatasan waktu yang diberikan ibu untuk merawat bayi mereka karena beban kerja mereka. Banyak ibu bekerja di luar rumah dan sering keluar selama berjamjam dan kadang-kadang makanan tidak disiapkan untuk anggota keluarga lainnya di rumah. Frekuensi pemberian MP-ASI pada anak mungkin juga tergantung pada pendapatan keluarga.

\section{Jumlah Makanan Pendamping ASI}

Hasil penelitian tentang takaran pemberian MP ASI penelitian dapat dilihat pada tabel 4.1 menunjukan bahwa dari 40 responden takaran/jumlah pemberian MP ASI yang sesuai sebanyak 28 responden $(70 \%)$ dan tidak sesuai sebanyak 12 responden (30\%). Hasil ini hampir serupa dengan penelitian yang dilakukan oleh Chapagain (2013) 
mengenai faktor-faktor yang memengaruhi praktik pemberian MP-ASI pada ibu dengan anak usia 6 - 24 bulan di Nepal. Hasil tersebut menunjukkan bahwa sebanyak 834 responden $(75,82 \%)$ telah memberikan MP-ASI dengan jumlah yang sesuai.

Pemberian MP-ASI harus dimulai dengan jumlah makanan yang sedikit, dan jumlah tersebut dapat ditingkatkan seiring dengan bertambahnya usia bayi ${ }^{[16]}$. Menurut Jafar (2012) dan WHO (2009) banyaknya pemberian makan pada bayi usia usia 6 - 8 bulan sebanyak 2 - 3 sendok makan penuh setiap kali makan ditingkatkan secara perlahan sampai $1 / 2$ (setengah) mangkuk berukuran $250 \mathrm{ml}$ (200 kkal/hari). Bayi usia 9 - 11 bulan banyaknya $1 / 2$ (setengah) sampai $3 / 4$ (tiga perempat) mangkuk berukuran $250 \mathrm{ml}$ (300 kkal/hari). Usia 12 - 23 bulan banyaknya $3 / 4$ (tiga perempat) sampai 1 (satu) mangkuk ukuran $250 \mathrm{ml}$ (550 $\mathrm{kkal} / \mathrm{hari})$. Jumlah MP-ASI yang dibutuhkan meningkat seiring bertambahnya usia anak dan berkurangnya asupan ASI.

Selanjutnya, responden lain dengan takaran/jumlah pemberian MP ASI yang tidak sesuai dalam penelitian ini adalah sebanyak 12 responden. Menurut WHO (2009), ketika diberikan MP-ASI maka bayi cenderung lebih jarang menyusui dan asupan ASInya berkurang, sehingga MPASI tersebut secara efektif menggantikan asupan ASI. Apabila MP-ASI lebih banyak energi yang dilarutkan daripada ASI, asupan energi total bayi mungkin lebih rendah daripada pemberian ASI eksklusif sehingga dapat menyebabkan malnutrisi.

\section{Berat Badan Bayi}

Hasil pengukuran berat badan pada bayi usia 6 - 12 bulan yang didapatkan dari 40 responden 33 responden $(82.5 \%)$ mengalami kenaikan berat badan dan responden yang tidak mengalami kenaikan berat badan sebanyak 7 responden (17.5\%). Menurut Kemenkes RI (2010) status pertumbuhan berdasarkan grafik pertumbuhan anak dalam KMS Naik (N) jika grafik $\mathrm{BB}$ mengikuti garis pertumbuhan atau kenaikan BB sama dengan KBM (kenaikan BB minimal) atau lebih dan Tidak Naik (T) jika grafik BB mendatar atau menurun memotong garis pertumbuhan di bawahnya atau kenaikan BB kurang dari KBM. Hasil dari penelitian menunjukan bahwa sebagian besar bayi mengalami kenaikan berat badan yaitu sebanyak 33 responden $(82.5 \%)^{[34]}$.

Menurut Soetjiningsih pada masa bayi pada umur satu tahun pertama merupakan tumbuh kembang yang sangat pesat dengan pesatnya pertumbuhan fisik tersebut maka perlu asupan yang baik. Setelah bayi berusia 6 bulan harus mendapat tambahan makanan yang bergizi. Hal ini sejalan dengan teori yang dikemukakan oleh Hidayat (2008) pertumbuhan berat badan bayi pada usia 6 - 12 bulan terjadi penambahan setiap minggu sekitar 25 - 40 gram dan pada akhir bulan ke - 12 akan terjadi penambahan tiga kali lipat berat badan lahir. Menurut Jafar (2010) bayi yang memperoleh asupan gizi yang sesuai akan mencapai pertumbuhan yang optimal.

Selanjutnya, dalam penelitian ini jumlah bayi yang tidak mengalami kenaikan berat badan yaitu sebanyak 7 bayi (17.5\%); di mana yang tidak mengalami kenaikan berat badan didapatkan pada status pertumbuhan grafik pertumbuhan dalam KMS menunjukkan 7 bayi grafik berat badannya mendatar dan kenaikan berat badan kurang dari KBM, 6 bayi lainnya pada KMS menunjukan grafik berat badan yang menurun dan kenaikan berat badan kurang dari KBM.

Menurut Michaelsen et al. (2017) hal ini dapat disebabkan oleh kualitas pemberian MP-ASI yang tidak adekuat. Pemberian MP-ASI dapat memengaruhi pertumbuhan, perkembangan, dan kesehatan jangka pendek maupun jangka panjang bayi. Oleh karena itu penting untuk memeriksa pemberian MP-ASI 
yang optimal selama periode 6-24 bulan, baik dari segi bentuk, frekuensi, maupun jumlah.

Selain penjelasan di atas, menurut Soetjiningsih penurunan berat badan dapat disebabkan oleh penyakit, tidak ada nafsu makan dalam waktu yang lama, dan kemiskinan. Menurut Widyastuti (2004) berat badan merupakan suatu tolak ukur untuk menentukan tingkat kesehatan anak. Berat badan akan menggambarkan komposisi tubuh bayi secara keseluruhan mulai dari kepala, leher, dada, perut, tangan dan kaki. Berat badan bayi yang rendah menunjukan kondisi bayi yang kurang sehat. Sebaliknya, jika berat badan bayi menunjukan kisaran pola standar, dapat dipastikan bayi dalam keadaan sehat. Jika berat badan bayi kurang dari yang seharusnya, makanan yang diberikan harus ditambah baik jumlah maupun kandungan gizinya.

Berat badan merupakan indikator yang sangat sensitif untuk memantau pertumbuhan anak. Bila kenaikan berat badan anak lebih rendah dari yang seharusnya, pertumbuhan anak terganggu dan anak berisiko mengalami kekurangan gizi. Sebaliknya bila kenaikan berat badan lebih besar dari yang seharusnya merupakan indikasi risiko kelebihan gizi $^{[34]}$. Menurut Hayati (2009) bayi sangat peka dan halus, pertumbuhan dan perkembangan bayi sangat dipengaruhi pola pemberian makan.

\section{Hubungan Pola Pemberian Makanan Pendamping ASI dengan Berat Badan Bayi Usia 6-12 Bulan \\ 1. Hubungan Bentuk MP ASI dengan Berat Badan Bayi}

Dari analisa data menggunakan uji statistik Chi-square didapatkan nilai $\mathrm{p}=0.02$. Karena nilai $\mathrm{p}$ kurang dari 0.05 maka hipotesis diterima artinya bahwa ada hubungan jenis/bentuk MP ASI dengan berat badan bayi. Pada penelitian ini ditemukan bahwa bayi yang mendapat bentuk MP_ASI sesuai umur memiliki kemungkinan 18.75 kali lebih besar memiliki mengalami kenaikan berat badan sesuai umur $(\mathrm{OR}=18.75 ; \mathrm{p}=0.02)$. Hal ini dapat terlihat pada bayi yang jenis/bentuk MP ASI yang sesuai berat badannya naik yaitu pada grafik pertumbuhan di KMS menunjukan bahwa grafik berat badan mengikuti garis pertumbuhan dan kenaikan berat badan sama atau lebih dengan KBM (Kenaikan BB Minimal). Bayi tersebut memiliki pola makanan pendamping ASI pada bentuk MP ASI yang sesuai anjuran yaitu sesuai dengan umur bayi.

Hal ini sejalan dengan penelitian Dewi (2010) berjudul Hubungan Pola Pemberian Makanan Pendamping ASI dengan status gizi pada balita usia 6 12 bulan di Desa Kaliori Kecamatan Kalibagor Kabupaten Banyumas menyatakan bahwa bayi yang memiliki pertumbuhan berat badan yang optimal disebabkan oleh pola pemberian MPASI sudah baik sedangkan pertumbuhan berat badan yang tidak sesuai dengan usia karena pola pemberian MP-ASI yang tidak mencukupi.

Pola pemberian MP ASI pada anak dapat dipengaruhi oleh pengetahuan orang tua. Rendahnya pengetahuan orang tua mengenai praktik pemberian MP ASI dapat berdampak pada tidak tepatnya bentuk MP ASI yang diberikan dengan usia anak $^{[42][47][57]}$. Salah satu penelitian Chouraqui et al. (2017) menemukan pemberian bentuk MP ASI yang tidak sesuai umur. Pada penelitian tersebut didapatkan hasil bahwa bayi usia 8 bulan telah mendapat bentuk MP ASI sama dengan makanan keluarga (orang dewasa). European Food Safety Authority (2009) menunjukkan bahwa bayi mampu untuk mengkonsumsi konsistensi padat "makanan keluarga" pada usia 12 bulan, bahkan jika mereka sering masih disajikan makanan semipadat.

Menurut Abeshu et al. (2016), untuk meningkatkan pertumbuhan 
optimal anak, sangat disarankan untuk meningkatkan konsistensi makanan secara bertahap seiring usia bayi bahkan ketika itu akan menghasilkan waktu menyusui yang lebih lama bagi para pengasuh. Makanan dapat menyebabkan tersedak dengan masuk atau menghalangi jalan udara harus dihindari. Risiko tersedak saat menelan makanan tertentu sering sering terjadi karena ukuran makanan (potongan kecil, tetapi keras, yang mungkin masuk ke jalan napas dan potongan lebih besar yang lebih sulit untuk dikunyah sehingga potongan yang dapat menghalangi saluran udara), bentuk (bentuk bola atau silinder yang dapat menghalangi saluran udara), dan konsistensi (makanan keras, halus, atau licin yang mungkin menyelinap ke tenggorokan; makanan kering atau keras; makanan lengket atau keras yang mungkin tidak mudah pecah dan mungkin sulit dihilangkan dari saluran udara).

Di sisi lain, menurut Waliyo (2017) makanan yang terlalu cair memiliki kandungan air yang tinggi sehingga kandungan energinya juga rendah. Kulwa et al. (2015) menyatakan bahwa konsumsi bubur encer atau lembek yang berkepanjangan menyebabkan bayi kekurangan energi dan asupan nutrisi dan malnutrisi kronis. Berdasarkan penjelasan tersebut, maka kesalahan dalam pemberian MP ASI ini dapat memengaruhi pertumbuhan berat badan anak.

Praktik pemberian MP ASI yang tidak tepat, termasuk jenis dan bentuk MP ASI berkontribusi dalam terjadinya gizi buruk pada bayi dan anak-anak dengan masalah yang paling umum terjadi adalah kurangnya asupan protein dan nutrisi mikro. Bayi dan anak-anak yang mendapatkan MP ASI tinggi asam fitat dan rendah mikronutrien berisiko mengalami gizi kurang. Hal ini dikarenakan asam fitat mengganggu penyerapan nutrisi dari makanan yang telah dikonsumsi ${ }^{[39]}$. Di sisi lain, menurut Rose et al. (2017) keputusan awal tentang pemberian ASI, dan jenis makanan padat yang ditawarkan pada masa bayi dapat menunjukkan pola diet dan risiko obesitas di kemudian hari. Bayi yang ditawari makanan padat energi memiliki asupan makanan yang lebih tinggi pada usia 6 tahun.

Keterlambatan orang tua dalam memberikan makanan padat pada bayi dapat masalah pemberian makan pada anak di kemudian hari dapat menyebabkan anak menjadi pemilih makanan (picky eater) $)^{[9]}$. Hal ini sejalan dengan penelitian Harris dan Coulthard (2016) di Inggris bahwa bayi yang pada akhir tahun pertama masih mendapatkan makanan lembek atau halus akan cenderung lebih sulit untuk menerima makanan dengan tekstur lebih kasar ketika masa balita dan anak-anak. Sehingga, meskipun pemberian MP ASI yang tepat membawa manfaat kesehatan pada anak usia 6-23 bulan, namun apabila pemberian MP ASI tidak tepat dapat meningkatkan risiko masalah berat badan dan kekurangan gizi pada masa balita dan anak-anak ${ }^{[50]}$.

2. Hubungan Frekuensi Pemberian MP ASI dengan Berat Badan Bayi

Analisa data menggunakan uji statistik Chi-square didapatkan nilai $\mathrm{p}=0.04$. Karena nilai $\mathrm{p}$ kurang dari 0.05 maka hipotesis diterima artinya bahwa ada hubungan frekuensi MP ASI dengan berat badan bayi. Pada penelitian ini ditemukan bahwa bayi yang mendapat frekuensi pemberian MP-ASI tepat sesuai umur memiliki kemungkinan 11.25 kali lebih besar mengalami kenaikan berat badan yang sesuai umur $(\mathrm{OR}=11.25 ; \mathrm{p}=0.04)$.Penelitian ini sejalan dengan penelitan Waliyo et al. (2017), bahwa terdapat hubungan yang bermakna antara jumlah pemberian MP ASI dengan status gizi bayi $(\mathrm{p}=0.000)$. 
Menurut Sulistyoningsih (2012) bayi yang sehat dan tercukupi kebutuhan gizinya akan mencapai pertumbuhan yang sesuai dengan usianya. Hasil penelitian ini didukung penelitian oleh Sakti (2013) berjudul Hubungan Pola Pemberian MP-ASI dengan Status Gizi Anak Usia 6-23 bulan di Wilayah Pesisir Kecamatan Tallo Kota Makassar Tahun 2013 menunjukan bahwa lebih banyak anak berstatus gizi buruk/kurang yang mendapatkan frekuensi pemberian MPASI kurang yaitu sebanyak 26 anak (38.2\%).

Aguayo (2017) menemukan bahwa frekuensi makan minimum dan keragaman diet minimum berhubungan positif dengan tinggi badan pada anak usia 6-23 bulan. Kombinasi frekuensi makan minimum dan keragaman diet minimum memiliki efek terbesar pada indikator pertumbuhan anak. Menurut Corsi et al. (2016), jumlah keragaman makanan yang rendah juga berpengaruh terhadap masalah berat badan lain, yaitu stunting.

Beberapa faktor seperti usia anak-anak, pendidikan ibu, pendidikan ayah, status pekerjaan ayah, status sosial ekonomi, paparan media massa, kerawanan pangan, tempat tinggal dan wilayah tempat tinggal secara signifikan berhubungan dengan frekuensi pemberian MP $\mathrm{ASI}^{[37]}$. Hal ini sejalan dengan penelitian di Bangladesh yang menemukan bahwa bayi usia 6-23 bulan dengan frekuensi MP ASI kurang akan memiliki risiko mengalami gizi kurang yang lebih besar ketika balita dibandingkan dengan yang mendapat MP ASI frekuensi cukup. Kendala ekonomi, rendahnya pengetahuan, dan kesadaran mengenai frekuensi pemberian MP ASI menjadi faktor yang berpengaruh terhadap rendahnya asupan gizi pada masa anak-anak ${ }^{[7]}$.

Variasi frekuensi pemberian MP

ASI berbeda-beda pada tingkat individu, rumah tangga, dan masyarakat. Sebagai contohnya, frekuensi pemberian MP ASI pada kelompok usia 6-11 bulan lebih rendah dibandingkan dengan kelompok usia 16-23 bulan. Selain itu juga didapatkan hasil bahwa frekuensi pemberian MP ASI akan bertambah seiring bertambahnya usia anak, namun kadang variasi MP ASI tidak mengalami perubahan yang signifikan $^{[37]}$. Padahal frekuensi dan keragaman makanan terutama pada anak di bawah dua tahun merupakan hal yang penting. Keragaman makanan yang rendah dan pemberian MP ASI yang tidak cukup akan meningkatkan risiko gizi kurang ${ }^{[35]}$.

\section{Hubungan Takaran Pemberian MP} ASI dengan Berat Badan Bayi

Analisa data menggunakan uji statistik Chi-square didapatkan nilai $\mathrm{p}<0.001$ dan alpha $=0.05$. Karena nilai $\mathrm{p}$ kurang dari 0.05 maka hipotesis diterima artinya bahwa ada hubungan takaran pemberian MP ASI dengan berat badan bayi. Pada penelitian ini ditemukan hasil bahwa bayi yang mendapat jumlah takaran MP_ASI tepat sesuai umur memiliki kemungkinan 27 kali lebih besar mengalami kenaikan berat badan yang sesuai umur $(\mathrm{OR}=$ 11.25; $\quad \mathrm{p}<0.001)$. Penelitian yang dilakukan oleh Kulwa et al. (2015) menemukan bahwa praktik pemberian makan yang tidak memadai, kandungan gizi yang rendah dari makanan pendamping ASI, dan pola makan yang rendah terhadap kebutuhan gizi berkontribusi pada tingginya prevalensi kekurangan gizi kronis (misalnya stunting) di antara bayi di pedesaan Dodoma.

Menurut WHO dalam Abeshu et al. (2016) jumlah makanan per hari tergantung pada kebutuhan energi setiap usia, kapasitas lambung anak, dan kepadatan energi makanan (kilokalori per gram). Jadi, untuk interval usia tertentu dan tingkat asupan ASI, menghitung jumlah makanan yang direkomendasikan 
memerlukan informasi tentang kepadatan energi makanan. Untuk anak-anak yang lebih besar yang membutuhkan jumlah makanan yang lebih banyak dalam sehari, makanan harus dibagi menjadi beberapa porsi dibandingkan dengan rekan-rekan mereka yang lebih muda.

$$
\text { Menurut Marimbi }
$$
memberikan makanan pendamping ASI sebaiknya diberikan secara bertahap pada jumlah porsinya. Jumlah pemberian makanan harus disesuaikan dengan keterampilan dan kesiapan bayi dalam menerima makanan. Menurut Suyitno kecukupan pangan esensial baik kualitas maupun kuantitas sangat penting untuk pertumbuhan normal. Hal ini sejalan dengan penelitian oleh Susanty (2012) dengan judul hubungan pola pemberian ASI dan MP ASI dengan gizi buruk pada anak 6 - 24 bulan di Kelurahan Pannampu Makassar bahwa terdapat hubungan yang signifikan antara pola pemberian MP ASI (konsumsi kalori) dengan kejadian dan merupakan salah satu faktor risiko gizi buruk.

Menurut penelitian yang dilakukan Aguayo et al. (2015) di Bhutan, praktik pemberian makanan pendamping yang direkomendasikan cenderung dikaitkan dengan kemungkinan stunting yang lebih rendah, terutama pada tahun pertama kehidupan. Secara khusus, anak-anak yang tidak diberi makanan pendamping yang cukup pada 6-8 bulan memiliki peluang tiga kali lipat lebih tinggi untuk mengalami stunting parah daripada anakanak yang diberi makan makanan pendamping yang cukup. Penelitian yang dilakukan Kulwa et al. (2015) di Tanzania menemukan bahwa ukuran porsi yang tidak memadai kemungkinan besar akan menyebabkan asupan makanan yang tidak memadai. Kepadatan energi (kkal/g) dan ukuran porsi (g) makanan telah diidentifikasi sebagai dua sifat makanan yang menunjukkan asupan energi.

$$
\text { Lanou et al. (2019) pada }
$$
penelitiannya di Burkina Faso menemukan bahwa terjadi penurunan tren pada praktik pemberian ASI, pemberian makanan padat, semi padat atau lunak yang tepat waktu, dan frekuensi minimum pemberian makanan pendamping ASI. Meskipun alasannya belum diketahui, namun penurunan tren tersebut berkontribusi terhadap meningkatnya prevalensi masalah berat badan seperti stunting, wasting, dan underweight pada anak usia 6-23 bulan.

Menurut Inayati et al. (2012), pemberian edukasi mengenai praktik pemberian MP ASI merupakan salah satu upaya untuk meningkatkan pengetahuan dan praktik pemberian MP ASI yang tepat, sehingga dapat mengurangu risiko gizi kurang pada balita dan anak-anak. Startegi pendidikan kesehatan ini dapat difokuskan terutama pada budaya-budaya dan mitos mengenai praktik pemberian MP ASI sesuai dengan daerah yang ditargetkan.

\section{Simpulan}

\section{KESIMPULAN}

1. Sebagian besar ibu bayi memiliki pola pemberian makanan pendamping ASI yang sesuai, meliputi:

a. Sebagian besar bayi usia $6-12$ bulan memiliki bentuk MP-ASI sesuai anjuran yaitu sebesar 70\%;

b. Sebagian besar bayi usia $6-12$ bulan memliliki frekuensi MP-ASI yang sesuai anjuran yaitu sebesar $62,2 \%$;

c. Sebagian bayi usia 6 - 12 bulan memiliki takaran/jumlah MP-ASI yang sesuai anjuran yaitu sebesar $72 \%$.

2. Sebagian besar bayi usia 6 - 12 bulan mengalami kenaikan berat badan yaitu sebesar \%.

3. Dari hasil uji statistik Chi-Square diperoleh:

a. Nilai $p=0,000$ yang berarti terdapat hubungan antara bentuk MP-ASI dengan berat badan bayi usia 6 - 12 bulan di Kelurahan Wonorejo.

b. Nilai $p=0,000$ yang berarti terdapat hubungan antara frekuensi MP-ASI 
dengan berat badan bayi usia 6 - 12 bulan di Kelurahan Wonorejo.

c. Nilai $\mathrm{p}=0,000$ yang berarti terdapat hubungan antara jumlah MP-ASI dengan berat badan bayi usia 6 - 12 bulan di Kelurahan Wonorejo.

\section{Saran}

1. Bagi Ibu Bayi dan Keluarga

Bagi ibu bayi maupun anggota keluarga lain dapat selalu memperhatikan pola pemberian makanan pendamping ASI yang diberikan kepada bayinya dengan disesuaikan umur bayi, baik dari segi bentuk, frekuensi, maupun jumlahnya. Selain itu, ibu bayi dapat menimbangkan bayinya secara rutin ke posyandu.

2. Bagi Dinas Kesehatan Kabupaten Karanganyar

Dinas Kesehatan Kabupaten Karanganyar perlu menyusun strategi upaya yang tepat dalam peningkatan status gizi balita di Kelurahan Wonorejo. Hal tersebut dapat dilakukan dengan melaksanakan pemberdayaan secara berkala kepada ibu maupun keluarga bayi mengenai pengelolaan pemberian makanan pendamping ASI untuk mencapai berat badan yang optimal menggunakan media yang tepat.

3. Bagi Kader Posyandu

Bagi kader posyandu diharapkan dapat memberikan motivasi dan arahan kepada ibu bayi maupun anggota keluarga lain untuk membawa bayinya ke posyandu secara rutin setiap bulan guna menimbang berat badan bayi. Selain itu, kader posyandu juga perlu memberikan umpan balik kepada ibu bayi maupun anggota keluarga lain setiap status pertumbuhan yang didapatkan pada penimbangan sehingga target berat badan yang optimal dapat dicapai.

4. Bagi Peneliti Selanjutnya

Bagi peneliti selanjutnya dapat menambahkan variabel lain yang merupakan determinan praktik pemberian makanan pendamping ASI, seperti: faktor ekonomi, sosial, maupun demografi, sehingga diperoleh hasil penelitian yang lebih mendalam. Selain itu, peneliti selanjutnya dapat mengkaji lebih dalam mengenai faktor-faktor lain yang dapat memengaruhi berat badan bayi, seperti: faktor genetik, prenatal, maupun postnatal.

\section{DAFTAR PUSTAKA}

1. Abeshu, M. A., Lelisa, A., dan Geleta, B. 2016. Complementary Feeding: Review of Recommendations, Feeding Practices, and Adequacy of Homemade Complementary Food Preparations in Developing Countries - Lessons from Ethiopia. Frontiers in Nutrition, 3. doi:10.3389/fnut.2016.00041

2. Aemro, M., Mosele, M., Birhanu, Z., \& Atenafu, A. 2013. Dietary Diversity and Meal Frequency Practices among Infant and Young Children Aged 6-23 Months in Ethiopia: A Secondary Analysis of Ethiopian Demographic and Health Survey 2011. Journal of Nutrition and Metabolism Volume 2013, hlm: 2. doi: http://dx.doi.org/10.1155/2013/78293 $\underline{1}$

3. Aguayo, V. M. 2017. Complementary feeding practices for infants and young children in South Asia. A review of evidence for action post2015. Maternal \& Child Nutrition, Vol. 13, e12439. doi:10.1111/mcn.12439

4. Aguayo, V. M., Badgaiyan, N., dan Paintal, K. 2014. Determinants of Child Stunting in the Royal Kingdom of Bhutan: An In-depth Analysis of Nationally Representative Data. Maternal \& Child Nutrition, Vol. 11, Issue 3, hlm: 333-45. doi: $10.1111 / \mathrm{mcn} .12168$ 
5. Aritonang, I., 2006. Busung Lapar. Yogyakarta : Media Pressindo. pp.86

6. Chapagain, R.A. 2013. Factors Affecting Complementary Feeding Practices of Nepali Mothers for 6 Months to 24 Months Children. Journal of Nepal Health Research Council 2013 May; 11(24), hlm: 206

7. Chowdhury, M. R. K., Rahman, M. S., dan Khan, M. M. H. 2016. Levels and determinants of complementary feeding based on meal frequency among children of 6 to 23 months in Bangladesh. BMC Public Health, Vol. 16, No.1, hlm: 7. doi:10.1186/s12889016-3607-7

8. Corsi, D.J., Mejia-Guevara,I., dan Subramanian, S.V. 2016. Risk Factors for Chronic Undernutrition Among children in India: Estimating Relative Importance, Population Attributable Risk and Fractions. Social Sciences \& Medicine, Vol. 157, hlm: 165-85. doi: https://doi.org/10.1016/j.socscimed.20 $\underline{15.11 .014}$

9. Costantini, C., Harris, G., Reddy, V., Akehurst, L., \& Fasulo, A. 2018. Introducing Complementary Foods to Infants: Does Age Really Matter? A Look at Feeding Practices in Two European Communities: British and Italian. Child Care in Practice, 1-16. doi:10.1080/13575279.2017.1414033

10. Crum, J., Subedi, G. R., Mason, J., Mebrahtu, S., \& Dahal, P. 2013. Infant and Young Child Feeding Practices are Associated with Child Nutritional Status in Nepal. Analysis of the Nepal Demographic Health Survey, 2011. In Ministry of Health and Population and United Nations Children's Fund (UNICEF)). Nepal: Kathmandu

11. Damayanti, D. 2010. Makanan Pendamping ASI. Jakarta: Gramedia Pustaka Utama. Hlm: 7
12. Dewi, R.K., Pantiawati,I., dan Happinasari, O. 2011. Status Gizi Pada Balita Usia 6-12 Bulan di Desa Kaliori Kecamatan Kalibagor Kabupaten Banyumas Tahun 2010. https://www.semanticscholar.org/pape r/HUBUNGAN-POLA-

PEMBERIAN-MAKANANPENDAMPING-ASI-GIZI-DewiPantiawati/ff69a13aca5066927e51833 c0aa0baf8b58c25d3

13. Departemen Kesehatan RI Direktorat Jenderal Bina Kesehatan Masyarakat., 2006. Pedoman Umum Pemberian Makanan Pendamping Air Susu Ibu (MP - ASI) Lokal Tahun 2006. Jakarta : Depkes - RI. pp 26

14. Dinas Kesehatan Profinsi Jawa Tengah., 2012 Profil Kesehatan Profinsi Jawa Tengah Tahun 2012. pp 65

15. Dinas Kesehatan Kota Surakarta., 2013. Profil Kesehatan Kota Surakarta Tahun 2012. Tabel 44

16. Du Plessis, L.M, Kruger, H.S., \&, Sweet, L. 2013. Complementary Feeding: a Critical Window of Opportunity from Six Months onwards. South African Journal of Clinical Nutrition 2013, 26(3), hlm: 135

17. Dwiatuty, E., 2011. Makanan Pendamping ASI : Variasi Pure. Jakarta : Agro Media Pustaka. pp 3

18. European Food Safety Authority. 2009. Scientific opinion on the appropriate age for introduction of complementary feeding of infants. $\begin{array}{llll}\text { EFSA } & J & 2009 & 7(12): 1423 .\end{array}$ doi:10.2903/j.efsa.2009.1423

19. Fakultas Kedokteran Universitas Sebelas Maret Surakarta., 2014. Buku Pedoman Keterampilan Klinis untuk Semester I Sambung Rasa Menstruktur Wawancara, Vital Sign, Dasar - dasar Pemeriksaan Fisik, Antropometri, Rekam Medis. Fakultas 
Kedokteran Universitas Sebelas Maret Surakarta. 87-88

20. Handajani, S., 2007. Panduan Praktis Pemberian Air Susu Ibu (ASI) dan Makanan Pendamping ASI (MP ASI) Lokal. Surakarta : Access

21. Harris, G., \& Coulthard, H. 2016. Early Eating Behaviours and Food Acceptance Revisited: Breastfeeding and Introduction of Complementary Foods as Predictive of Food Acceptance. Current Obesity Reports, Vol. 5, Issue 1, hlm: 113-20. doi:10.1007/s13679-016-0202-

22. Hayati, A., 2009. Buku Saku Gizi Bayi. Jakarta : EGC. pp 6-14

23. Hidayat, A., 2008. Pengantar Ilmu Kesehatan Anak. Ed.1 Jakarta: Salemba Medika. Pp 15-16

24. Irmayanti, M., 2007. MPKT Modul I : Pengetahuan. Jakarta, Penerbitan FEUI

25. Istiany,A., 2013. Gizi Terapan. Bandung : Remaja Rosdakarya Offset. pp 94 dan 109

26. Ikatan Dokter Anak Indonesia (IDAI). 2018. Pemberian Makanan Pendamping Air Susu Ibu (MP ASI). http://www.idai.or.id/wpcontent/uploads/2018/10/BookletMPASI-revised-A-10-oktober2018.pdf - Diakses 28 Februari 2019

27. Inayati, D., Scherbaum, V., Purwestri, R., Hormann, E., Wirawan, N., Suryantan, J., Hartono, S., Bloem, M.A., Pangaribuam, R.V., Biesalski, H.K., dan Bellows, A. 2012. Infant Feeding Practices Among Mildly Wasted Children: A Retrospective Study on Nias Island, Indonesia. International Breastfeeding Journal, Vol. 7, Issue 1, hlm: 8. doi:10.1186/1746-4358-7-3

28. Jafar, N dkk., 2012. Modul Modul Pelatihan Edukasi Makanan Pendamping Air Susu Ibu (MP-ASI).
Makasar : Program Studi Ilmu Gizi Fakultas Kesehatan Masyarakat Universitas Hasanuddin

29. Jonni M S dkk., 2012. Cegah Malnutrisi dengan Kelor. Yogyakarta: Kanisius. pp 52,53

30. Kementerian Kesehatan Republik Indonesia (Kemenkes RI). 2017. Buku Saku Pemantauan Status Gizi tahun 2017.

http://sehatnegeriku.kemkes.go.id/wpcontent/uploads/2018/01/Buku-SakuNasional-PSG-2017-Cetak-1.pdf Diakses 27 Februari 2019

31.

Panduan Fasilitator Modul Pelatihan Konseling Pemberian Makan Bayi dan Anak (PMBA). Direktorat Jenderal Bina Gizi dan Kesehatan Ibu dan Anak: Jakarta

32. 2012.

Buku Pedoman Kegiatan Gizi dalam Penanggulangan Bencana. Direktorat Jenderal Bina Gizi dan Kesehatan Ibu dan Anak: Jakarta

33. Kementerian Kesehatan Republik Indonesia (Kemenkes RI). 2011. Makanan Sehat untuk Bayi. http://gizi.depkes.go.id/wpcontent/uploads/2013/09/BrosurMakanan-Sehat-untuk-Bayi1.pdf - 1 Maret 2019

34. Kementerian Kesehatan Republik Indonesia. 2010. Peraturan Menteri Kesehatn Republik Indonesia Nomor 155/Menkes/Per/I/2010 tentang Penggunaan Kartu Menuju Sehat (KMS) Bagi Balita. Hlm: 1

35. Khanal, V., Sauer, K., dan Zhao, Y. 2013. Determinants of Complementary Feeding Practices Among Nepalese Children Aged 6-23 Months: Findings from Demographic and Health Survey 2011. BMC Pediatrics, Vol 13 No. 131, hlm: 1-13. 
doi: $\quad$ https://doi.org/10.1186/14712431-13-131

36. Kulwa, K. B. M., Mamiro, P. S., Kimanya, M. E., Mziray, R., dan Kolsteren, P. W. (2015). Feeding Practices and Nutrient Nontent of Complementary Meals in Rural Central Tanzania: Implications for Dietary Adequacy and Nutritional Status. BMC Pediatrics, Vol. 15, No. 1, hlm: 6. doi:10.1186/s12887-0150489-2

37. Kuriyan, R dan Kurpad, A.V. 2012. Complementary Feeding Patterns in India. Nutrition, Metabolism, and CardiovascularDisease, Vol. 22, No. 10. doi: 10.1016/j.numecd.2012.03.012

38. Lanou, H. B., Osendarp, S. J. M., Argaw, A., De Polnay, K., Ouédraogo, C., Kouanda, S., \& Kolsteren, P. (2019). Micronutrient Powder Supplements Combined With Nutrition Education Marginally Improve Growth Among Children Aged 6-23 Months in Rural Burkina Faso: A Cluster-Randomized Controlled Trial. Maternal \& Child Nutrition, e12820. doi: $10.1111 / \mathrm{mcn} .12820$

39. Mesfin, A., Henry, C., Girma, M., dan Whiting, S.J. 2015. Use of Pulse Crops in Complementary Feeding of 6-23 Month-Old Infants and Young Children in Taba Kebele, Damot Gale District, Southern Ethiopia. Journal of Public Health in Africa, Vol. 6, No. 657. doi:10.4081/jphia.2015.357

40. Michaelsen, K.F., Grummer-Strawn, L., \& Bégin, F. 2017. Emerging Issues in Complementary Feeding: Global Aspects. Maternal \& Child Nutrition, 13, hlm: 5. doi:10.1111/men.12444

41. Mufida, L., Widyaningsih, T.D., \& Maligan, J.M. 2015. Prinsip Dasar Makanan Pendamping Air Susu Ibu (MP-ASI) untuk Bayi 6 - 24 Bulan:
Kajian Pustaka. Jurnal Pangan dan Agroindustri Vol. 3 No 4, September 2015, hlm: 1648

42. Nguyen, P.H., Menon, P., Ruel, M., dan Hajeebhoy, N. 2011. A Situational Review of Infant and Young Child Feeding Practices and Interventions in Viet Nam. Asia Pacific Journal of Clinical Nutrition, Vol. 20, Issue 2

43. Nurhayati, S. 2018. Hubungan Praktik Pemberian Makanan Pendamping ASI (MP-ASI) dengan Status Gizi Baduta di Kelurahan Sidorejo Kidul, Kecamatan Tingkir, Kota Sa latiga. Universitas Muhammadiyah Surakarta: Naskah Publiksi, hlm: 10. http://eprints.ums.ac.id/62829/1/NAS PUB.pdf - Diakses 15 Maret 2019

44. Olatona, F.A., Adenihun, J.O., Aderibigbe, S.A., \& Adeniyi, O.F. 2017. Complementary Feeding Knowledge, Practices, and Dietary Diversity among Mothers of UnderFive Children in an Urban Community in Lagos State, Nigeria. International Journal of $\mathrm{MCH}$ and AIDS (IJMA), 6(1), hlm: 51. doi:10.21106/ijma.203

45. Owais, A., Schwartz, B., Kleinbaum, D.G., Suchdev, P.S., Faruque, A.S.G., Das, S.K., \& Stein, A.D. 2016. Minimum Acceptable Diet at 9 Months but not Exclusive Breastfeeding at 3 Months or Timely Complementary Feeding Initiation is Predictive of Infant Growth in Rural Bangladesh. PloS One, 11(10): e0165128. doi: https://doi.org/10.1371/journal. pone. 0165128

46. Parson, M. R., Bahson, H. T., Logan, $\mathrm{K}$ et al. 2018. Association of Early Introduction of Sollds with Infant Sleep: A Secondary Analysis of Randomised Clinicnical Trial. Research Spotlight, Issue 3. 2018. doi: 10.1001/jamapediatrics.2018.0739 
47. Rahman, M., Chowdhury, R.H.K., Nager, S., Nazmul, H., dan Islam, S. 2017. Level of Consumption of Complementary Foods Among Underweight Children from 6 to 23 Monthsin Bangladesh. International Journal of Perceptions in Public Health, Vol. 1, No. 4, hlm: 228-34

48. Romero-Velarde, E., VillalpandoCarrión, S., Pérez-Lizaur, A.B., Iracheta-Gerez, M. de la L., AlonsoRivera, C.G., López-Navarrete, G.E., ... Pinacho-Velázquez, J.L. 2016. Guidelines for Complementary Feeding in Healthy Infants. Boletín Médico Del Hospital Infantil de México (English Edition), 73(5), hlm: 347.

doi:10.1016/j.bmhime.2017.11.007

49. Rose, C.M., Birch, L.L., dan Savage, J.S. 2017. Dietary Patterns in Infancy are Associated with Child Diet and Weighr Outcomes at 6 years. Internationa Journal of Obesity, Vol. 41, hlm: 783-8

50. Senarath, U., \& Dibley, M. J. (2011). Complementary feeding practices in South Asia: analyses of recent national survey data by the South Asia Infant Feeding Research Network. Maternal \& Child Nutrition, 8, 5-10. doi:10.1111/j.1740-8709.2011.00371.

51. Srivasatava, G., Bhatnagar, S., dan Khan, K.A. 2018. Complementary Feeding Practice of Children (6 months-23 months) in and around Lucknow, India. International Journal of Contemporary Pediatrics. Vol. 5, No. 1, 2018, hlm: 116. Doi: http://dx.doi.org/10.18203/23493291.ijcp20175570

52. Sulistyoningsih. 2011. Gizi untuk Kesehatan Ibu dan Anak. Ed.2. Yogyakarta: Graha Ilmu. Hlm: 164-76

53. The International Child Health Review Collaboration (ICHRC). 2016. Lampiran 5. Melakukan
Penilaian Status Gizi Anak. http://www.ichrc.org/lampiran-5melakukan-penilaian-status-gizi-anak - Diakses 1 Maret 2019

54. Udoh, E.E., \& Amodu, O.K. 2016. Complementary Feeding Practices among Mothers and Nutritional Status of Infants in Akpabuyo Area, Cross River State Nigeria. SpringerPlus, 5(1), hlm: 137. doi:10.1186/s40064-016-3751-

55. United Nations International Childrens's Emergency Fund (UNICEF). 2018. Improving Breastfeeding, Complementary Food, and Feeding Practices. https://www.unicef.org/nutrition/index breastfeeding.html - Diakses 22 Februari 2018

56.

2018. Infant and Young Feeding. https://data.unicef.org/topic/nutrition/i nfant-and-young-child-feeding/ Diakses 18 Maret 2019

57. Waliyo, E., Marlenywati., dan Nurseha. 2017. Hubungan Pengetahuan Gizi dan Pola Pemberian Makanan Pendamping Asi Terhadap Status Gizi pada Umur 6-59 Bulan Di Wilayah Kerja Puskesmas Selalong Kecamatan Sekadau Hilir Kabupaten Sekadau. Jurnal Kedokteran dan Kesehatan., Vol. 13, No.1, hlm: 61-9

58. World Health Organization (WHO). 2019. Appropriate Complementary Feeding.

https://www.who.int/elena/titles/comp lementary feeding/en/ - Diakses 14 Mei 2019

59.

2019. Complementary Feeding.

https://www.who.int/nutrition/topics/c omplementary_feeding/en/ - Diakses 22 Februari 2019

60. 2009. Infant and Young Child 
PLACENTUM Jurnal Ilmiah Kesehatan dan Aplikasinya, Vol.8(1) 2020

Feeding.

https://www.ncbi.nlm.nih.gov/books/
NBK148965/pdf/Bookshelf_NBK148

965.pdf - Diakses 22 Februari 2019 
PLACENTUM Jurnal Ilmiah Kesehatan dan Aplikasinya, Vol.8(1) 2020 